\title{
Limits to nitrogen fertilizer on grassland
}

W. H. Prins (Institute for Soil Fertility, P.O. Box 30003, 9750 RA Haren, Netherlands; seconded by the Netherlands Fertilizer Institute, NMI)

Received 12 September 1984; accepted 16 October 1984

\begin{abstract}
The effect of nitrogen fertilizer on seasonal response of grassland, sward quality and productivity, herbage nitrate content, and soil mineral nitrogen was studied in cutting trials lasting one to six years. At an assumed marginal profitability of $7.5 \mathrm{~kg}$ dry matter per $\mathrm{kg} \mathrm{N}$ applied, the average 'optimum' $\mathrm{N}$ application on sand and clay soils was $420 \mathrm{~kg} \mathrm{ha}^{-1} \mathrm{yr}^{-1}$. At this rate, herbage nitrate content did not exceed $0.75 \% \mathrm{NO}_{3}$ and accumulation of soil mineral $\mathrm{N}$ was minimal. At $\mathrm{N}$ rates exceeding $500 \mathrm{~kg} \mathrm{ha}^{-1} \mathrm{yr}^{-1}$ sward quality deteriorated to such an extent that productivity decreased in the following year.

Key-words: grassland, nitrogen fertilization, productivity, nitrogen uptake, herbage nitrate content, soil mineral nitrogen, residual effect.

Introduction. With increasing intensification of dairy farming around 1970 in the Netherlands $\mathrm{N}$ fertilizer dressings higher than the recommended 350 to $400 \mathrm{~kg} \mathrm{ha}^{-1}$ $\mathrm{yr}^{-1}$ were sometimes applied to grasslands on sand and clay soils. The question arose what effect such high dressings would have on seasonal response of grassland, sward quality and productivity, herbage nitrate content and soil mineral nitrogen status.
\end{abstract}

Materials and methods. The effect of $\mathrm{N}$ fertilizer was studied in cutting trials lasting from one to six years. $\mathrm{N}$ rates per cut varied from 0 to $160 \mathrm{~kg} \mathrm{ha}^{-1}$, totalling up to over $1000 \mathrm{~kg} \mathrm{ha}^{-1} \mathrm{yr}^{-1}$. Plots were cut at a set stage of growth, namely when a dry matter yield level of 2 to $2.5 \mathrm{t} \mathrm{ha}^{-1}$ was reached. Because of faster grass growth at the higher rates of $\mathrm{N}$ this technique meant that the frequency of cutting increased with the higher rates of $\mathrm{N}$ application.

Trials were conducted on old permanent and on recently sown grasslands on sand and clay soils. In the all-grass swards perennial ryegrass (Lolium perenne $\mathrm{L}$.) was the dominant component or virtually the only grass species.

Results. The response to $\mathrm{N}$ was strongest in the first half of the season and declined gradually during the second half. The higher the rate of $\mathrm{N}$, the weaker was the response to $\mathrm{N}$ later in the season. This decrease in response was associated with the residual effect of previously applied $\mathrm{N}$. The variation in $\mathrm{N}$ response was considerable and was related to locations and years. At a level of $N$ per cut of $40 \mathrm{~kg} \mathrm{ha}^{-1}$ there was towards the end of the season a positive response to $\mathrm{N}$ up to a dressing of $120 \mathrm{~kg}$ $\mathrm{ha}^{-1}$. But at a much more intensive level of fertilization there was little or no re- 


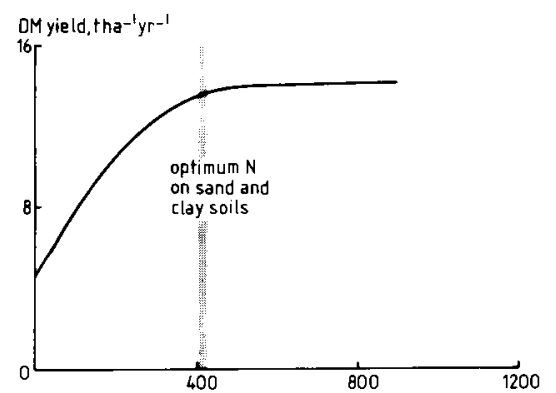

Fig. 1. Limits to nitrogen fertilizer on grassland as shown by the relationship between fertilizer nitrogen application and dry matter (DM) yield, herbage nitrogen uptake, herbage nitrate content and soil mineral nitrogen accumulation from beginning to end of the season, respectively. Source: three longterm trials on sand and clay soils during 1974-1980.
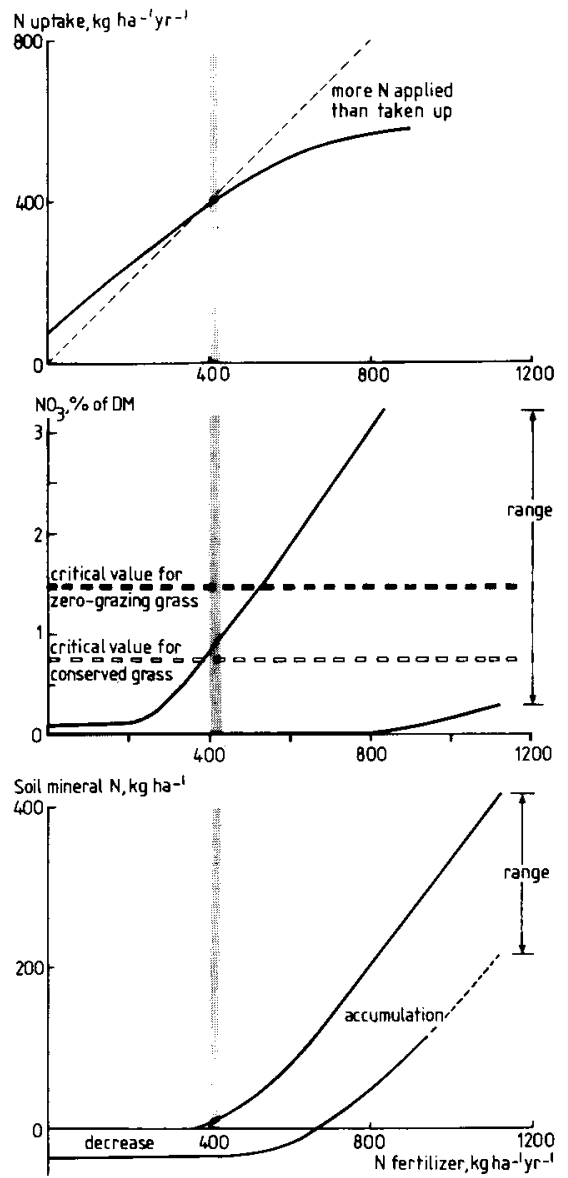

sponse towards the end of the season and an application of $120 \mathrm{~kg} \mathrm{ha}^{-1}$ could even give a negative response. At such a high level the sward had become more open.

With increasing rates of $\mathrm{N}$, but especially after applications totalling $500 \mathrm{~kg}$ and more in precedings years, productivity was lower in the subsequent year. This decrease was associated with changes in sward characteristics such as percentage cover and number of tillers. As a result of the change in productivity the response to $\mathrm{N}$ 
in the first year of the long-term trials (up to at least $720 \mathrm{~kg} \mathrm{ha}^{-1} \mathrm{yr}^{-1}$ ) was higher than that in subsequent years. The study showed that one-year trials may give too optimistic a picture of the $\mathrm{N}$ response.

The nitrate content of the harvested herbage was determined at every cut. In the long-term trials there was little or no increase in nitrate contents at $\mathrm{N}$ applications per cut of $60 \mathrm{~kg} \mathrm{ha}^{-1}$, with a maximum of $360 \mathrm{~kg} \mathrm{ha}^{-1} \mathrm{yr}^{-1}$. At $80 \mathrm{~kg} \mathrm{~N}$ per cut, totalling $400-560 \mathrm{~kg} \mathrm{ha}^{-1} \mathrm{yr}^{-1}, 3 \%$ of the samples had $\mathrm{NO}_{3}$ contents higher than $0.75 \%$, nowadays in the Netherlands the critical value for pre-wilted silage and hay when fed twice daily. At $\mathrm{N}$ applications of 120 and $160 \mathrm{~kg}$ per cut, totalling $600-1120 \mathrm{~kg}$ ha $^{-1} \mathrm{yr}^{-1}, 61$ and $67 \%$ of the samples exceeded $0.75 \% \mathrm{NO}_{3}$, while 19 and $47 \%$ of the samples even exceeded $1.50 \% \mathrm{NO}_{3}$, the critical value for zero-grazing grass when fed twice daily. Nitrate accumulation mostly occurred in summer grass and seldom in autumn grass.

Within one season soil mineral $\mathrm{N}$ remained constant per cut at $60 \mathrm{~kg} \mathrm{~N}^{-1}$ (with seven cuts totalling $420 \mathrm{~kg} \mathrm{ha}^{-1} \mathrm{yr}^{-1}$ ). With $80 \mathrm{~kg} \mathrm{~N}$ per cut accumulation started in $\mathrm{Au}-$ gust after six applications, while at $120 \mathrm{~kg}$ per cut accumulation started as early as May after only two applications. Over successive growing seasons $\mathrm{N}$ accumulation occurred on old permanent grassland with split applications totalling more than 400 $\mathrm{kg} \mathrm{ha}^{-1} \mathrm{yr}^{-1}$, and on young grassland, sown after arable crops, totalling more than $480 \mathrm{~kg} \mathrm{ha}^{-1} \mathrm{yr}^{-1}$.

When $\mathrm{N}$ was applied at 480 or more $\mathrm{kg} \mathrm{ha}^{-1}$, approximately 25,40 and $50 \%$ of the annual $\mathrm{N}$ application minus $\mathrm{N}$ uptake $\left(\mathrm{N}_{E X C}\right.$, defined as the amount of $\mathrm{N}$ applied exceeding the amount of $\mathrm{N}$ harvested) was recovered in the following spring as accumulated mineral nitrogen in the $0-100 \mathrm{~cm}$ layer of slightly loamy sand, clay and heavy clay soils, respectively. $\mathrm{N}_{\mathrm{EXC}}$ had no effect on dry matter yield or nitrogen yield on the sandy soil but it had a distinct effect on the clay soils in the following season. The accumulated soil mineral nitrogen appeared to be as effective as freshly applied fertilizer $\mathrm{N}$.

The overall results of the study are summarized in Fig. 1. At an assumed marginal profitability of $7.5 \mathrm{~kg}$ dry matter per $\mathrm{kg} \mathrm{N}$ applied, the 'optimum' $\mathrm{N}$ application in the long-term trials on sand and clay soils was $420 \mathrm{~kg} \mathrm{ha}^{-1} \mathrm{yr}^{-1}$, with a range of 360$520 \mathrm{~kg}$. At this 'optimum' the risks of herbage $\mathrm{NO}_{3}$ accumulation above $0.75 \%$ and of soil mineral $\mathrm{N}$ accumulation were minimal. The 'optimum' application is close to the present recommendation of $400 \mathrm{~kg} \mathrm{ha}^{-1} \mathrm{yr}^{-1}$ for intensively managed grassland on sand and clay soils in the Netherlands.

This synopsis is based on a doctoral thesis, Agricultural University, Wageningen, Netherlands, 1983. viii +132 pp, 43 figs., 33 tables, refs., 7 appendices. Parts of the thesis have been published in various journals and proceedings.

Available as paper copy (order R022P, $f 30$ including postage) or microfiches (order R022M, $f$ 17,50 including postage) at: NARD, clo Pudoc, P.O. Box 4, 6700 AA Wageningen, Netherlands (telex $45015 \mathrm{blhwg} \mathrm{nl}$ ). 